\title{
A Dream Betrayed
}

\author{
By Gerald Pratley
}

Spring 1997 Issue of KINEMA

Tony Manera: A Dream Betrayed: The Battle for the CBC. Toronto: Stoddart, 1996, 224pp. CAD 27.95. 8 pp. b\&w photo insert. ISBN: 0-7737-2980-1.

THE trials and tribulations of the Canadian Broadcasting Corporation -- mostly self-inflicted over the years -drag tiresomely on. Two books, The Dream Betrayed by Tony Manera, and Cue the Elephant! by Knowlton Nash, paint opposite sides of the dream. Manera's book is depressing in the extreme while Nash's book is light-hearted to the point of becoming light-headed.

Tony Manera, formerly with the CBC for ten years mainly on the engineering and technical side, became President of the Corporation in February 1994 and resigned a year later when the government reduced the CBC's parliamentary appropriations after having assured him, when he accepted the position, of its "undying political and financial support".

Having given his word to the staff of the CBC that there would be no more dismissals he felt duty-bound to resign when the budget was reduced to the extent that over one thousand employees would have to go -one way or the other. Feeling that his integrity was in question he resigned.

But did he have to make such a drastic move? There is no doubting his sincerity and concern in the story he tells of his troubled year, but would anyone at the CBC have thought the less of him had he remained knowing that it was the Cabinet that made the decision to cut the budget, not the President; and that it was the Minister who had gone back on his word, not Manera, and that further, so far as the Treasury was concerned, it was still giving the CBC its "undying and firm support" but somewhat less so?

We all know that Ministers of the Crown are loathe to resign when they fail to live up to their promises and responsibilities (Copps, Dingwall, Collenette) but Manera was a servant of the Crown, and could hardly be held responsible for decisions made in Cabinet. And what good came out of Manera's resignation? We are now saddled with the ineffective and unqualified Perrin Beatty.

So why did he resign? Was it only on the grounds of a promise broken and of integrity compromised? Reading Manera's 'behind the scenes' unfolding of events suggest other reasons. Was he perhaps out of his depths? Was this huge, sprawling, mismanaged, inefficient public body uncontrollable? Had he the strength to take it on and bring about the drastic changes needed to make it once again a truly public broadcaster?

What he should have asked of the Prime Minister was not to make promises about budgets that he couldn't keep but to give him the power to override a fractious, useless Board of Directors and to bring the CBC back to its basic intentions. The dream he talks about was betrayed years ago, before he came on the scene, not just during his one year in office.

But was Manera capable of doing this? Possibly not. The CBC needs a towering figure with the strength and the intellect of a John Grierson to rise above the common herd and ruthlessly remodel the CBC according to its means and original purpose. There are many individuals in programming who should have been fired years ago -- or never been taken on in the first place. Significantly, programming is hardly mentioned in Manera's wanderings.

His own annus horribilis is something of a puzzle. At times it reads like a social diary: I went here and I went there, I met with him and I met with her; praise is generously bestowed on the many individuals clustered around him -- except perhaps Board member Patrick Watson -- which is understandable. He trudged back and forth across the country giving talks to anybody who would listen, from premiers to politicians, from businessmen to the man-in-the-street, his discussions underlined with the veiled possibility of his resignation being tendered at any moment should matters get worse. Between being bombarded with facts and figures showing how awful matters have become are cosy black-and-white snapshots of Tony with friends and the famous. 
Did these well-meant efforts do any good? Who was minding the store? Could it be that when the budget cuts were announced it was with some relief that he handed in his resignation the burden of office having become too great? Now he could leave all the worries, troubles, arguments behind, retiring to his garden, his honour intact.

Interestingly, thinking perhaps of future appointments, he didn't state, as his reason for leaving, that the Prime Minister had let him down, and under the circumstances, he would not continue after this betrayal. Instead, he absolves the PM and Cabinet by saying that he was resigning "for personal reasons". This of course, left the Cabinet feeling itself blameless. "It wasn't our fault he left. He went for personal reasons". Manera admits that he realised later this was a mistake.

Whatever Manera's strengths and weaknesses were during his term in office it seems unbelievable that a man with his convictions about the need for the $\mathrm{CBC}$, and which all intelligent Canadians share, should defend the showing of commercials on the grounds that they bring in revenue. And what a paltry sum it is to constantly interrupt mainly creative and sensitive programmes with, for the most part, loud and mendacious sales promotions, to rip motion pictures to pieces and to drench Newsworld with the ravings of McCain's food products salesmen.

This is not public broadcasting. This is the betrayal of taxpayers let down by administrators who lack concern and the vision to think of other ways to cover costs. He defends bidding against private broadcasters for sports events. If there is money in the budget to pay for them without commercials, as the BBC does in the UK, then well and good. The CBC's coverage would no doubt be better. But to buy them on the grounds that commercials will cover the cost is entirely wrong. The CBC should certainly sell its programmes to broadcasting services at home and abroad to increase revenue but not sell its airtime, our airtime, to advertisers.

The time will probably come, governments being what they are, when, like the PBS (the American Public Broadcast System) and non-commercial TVOntario, we will have to accept programmes being sponsored and presented by companies through brief introductions but never to be interrupted by them. And how could Manera justify the time and money spent on appearances before the CRTC (Canadian Radio and Television Commission) to apply for a specialty channel and to become part of another proposed by private broadcasters?

Everything the $\mathrm{CBC}$ claims it would broadcast on additional channels, as with Newsworld, which is an unnecessary expense, should be on the CBC's main channel. But no, this would make the CBC like PBS and Channel 4 or Bravo!, which Manera, thinks, is 'elite' broadcasting. Why not ask why so many Canadians financially support the PBS in the United States? Behind all of this of course, is the obsession with ratings. The CBC should think of intelligent programming at all times and consider ratings as a matter of interest but never as a controlling factor in what it shows. The CBC cannot be all things to all audiences, as Manera seems to think.

\section{Author Information}

Gerald PRATLEY, OC, LLD, started his career as film critic with the CBC. In 1969, he founded the Ontario Film Institute which he directed until 1990. He has written several books and numerous articles on film, including Torn Sprockets, a history of Canadian cinema. He taught Film History in universities in Toronto and Waterloo, Canada and holds three honorary degrees from Canadian and US universities.

Gerald A. Pratley (1923-2011) was born and educated in London, England, and came to Canada in 1946. He started working in Toronto for the $\mathrm{CBC}$ as a scriptwriter. He was drawn toward working in motion pictures, and became, in 1948, the CBC's first film critic and commentator.

Gerald Pratley broadcast three programmes a week, Pratley at the Movies, The Movie Scene, Music From the Films, and others, until 1975. During this time he also became the first post-war chairman of the Toronto Film Society, chairman of the Toronto and District Film Council and co-founder of the A-G-E Film Society and correspondent for international magazines such as Films and Filming, Film In Review, Variety, 
Hollywood Quarterly and International Film Guide. During the 1950s he wrote for Canadian Film Weekly and Canadian Film Digest.

He became known as a speaker on all aspects of motion picture art and industry, and was invited to teach film history at the University of Toronto, York University, University of Waterloo, Seneca College and Ryerson Polytechnical University, with individual lectures being given at many other Canadian and US universities and colleges. He has served as a member of various judging panels of competitions and festivals, being one of the members of the first Canadian Film Awards in 1949.

From 1970 to 1975 he was the director of the Stratford (Ontario) International Film Festival, and from 1969 to 1976 he was Chairman of the International Jury of the Canadian Film Awards. He has attended all the world's leading festivals of film, and in particular, for 30 years, the Cannes Festival as CBC correspondent. He has written six books, The Films of Frankenheimer: Forty Years in Film; The Cinema of John Frankenheimer; The Cinema of Otto Preminger; The Cinema of David Lean; The Cinema of John Huston, and Torn Sprockets, a history of the Canadian cinema.

Gerald Pratley has served on the Advisory Boards of the film departments of Ryerson Polytechnical University and Humber College, and as a member of the programme committee of TV Ontario. In 1968 he became the founder-director of the Ontario Film Institute of the Province of Ontario, an organization which has distinguished itself in archival holdings and public service and is known since 1990 as the Cinematheque of Ontario. He taught Film History courses at the Department of Film and Photography, Ryerson Polytechnic University, Toronto and the University of Waterloo.

In 1984, Gerald Pratley was made a Member of the Order of Canada and in 2003 Officer of the Order of Canada for his service to Canada through film appreciation. He holds Honorary Degrees in Letters and Fine Arts from York and Waterloo Universities (Ont., Canada) and Bowling Green State University (Ohio, USA).

In 2002, Gerald Pratley received a Special Genie Award from the Academy of Canadian Cinema \& Television in recognition of his lifelong dedication to the promotion and his exceptional support of Canadian cinema.

He died on 14 March 2011 in Ontario, Canada. 